\title{
高温平面ひずみ圧縮変形によりAZ80マグネシウム合金に 形成される集合組織
}

\author{
金 珍旭 $*$ ·岡安 和人 **・福富 洋志**
}

Journal of The Japan Institute of Light Metals, Vol. 62, No. 2 (2012), 54-59

\section{Texture evolution in AZ80 magnesium alloy by the plane strain compression deformation at high temperature}

\begin{abstract}
Jinuk KIM*, Kazuto OKAYASU** and Hiroshi FUKUTOMI**
The formation behavior of textures during high temperature plane strain compression deformation is experimentally studied on AZ80 magnesium alloy. Three kinds of specimens with different initial textures are prepared from the extruded bars having a $\langle 10 \overline{1} 0\rangle$ fiber texture. Plane strain compression is conducted at $723 \mathrm{~K}, 5.0 \times 10^{-2} \mathrm{~s}^{-1}$ and strains ranging from -0.4 to -1.0 . New grains appeared after the deformation up to -0.4 in true strain. Initial texture gradually changes with increasing strain. After the deformation up to -1.0 in true strain, $(0001)\langle 10 \overline{1} 0\rangle$, $\{11 \overline{2} 0\}\langle 10 \overline{1} 0\rangle,(0001)\langle 11 \overline{2} 0\rangle$ and $\{10 \overline{1} 0\}\langle 0001\rangle$ appeared depending on the initial texture. $(0001)\langle 10 \overline{1} 0\rangle$ and $\{11 \overline{2} 0\}\langle 10 \overline{1} 0\rangle$ are formed irrespective of the initial texture. Simple crystallographic examination showed that all the texture components are orientations stable for the plane strain compression.
\end{abstract}

(Received June 30, 2011 Accepted October 1, 2011)

Keywords: high temperature, plane strain compression, texture, magnesium alloy

\section{1. 緒言}

軽量化の重要性が様々な分野で意識され，マグネシウム合 金への関心が近年高まっている。しかし，マグネシウム合金 は常温での加工が困難であることが障害となって，広範な利 用はいまだに実現していない。

マグネシウム合金も高温になると活動すべり系が増えて変 形能が大幅に向上するのでマグネシウム合金の加工は高温で 行われる ${ }^{1), 2)}$ 。高温での加工の際に形成される集合組織は, その後の室温での加工性だけでなく, 強度をはじめ多結晶体 の様々な特性に影響を及ぼす。それゆえ，マグネシウム合金 の高温変形下での集合組織形成挙動の把握と形成機構の解明 は，学問的のみならず工業的にも重要な課題である。

著者のうちの 2 人らは, $\mathrm{Al}-\mathrm{Mg}$ 二元系固溶体合金の高温変 形中の集合組織の形成挙動を単軸圧縮変形ならびに平面ひず み圧縮変形によって調べ，形成される集合組織の内容と発達 過程が変形条件に依存して大きく変わることを見出した。そ して，溶質原子雲囲気を引きずる転位の運動が変形を支配す るようになると，蓄積エネルギーの結晶方位依存性が高く なって，粒界移動が広範に生じて室温での変形集合組織とは 異なる優先方位からなる先鋭な集合組織が発達すると考えら れることを報告した ${ }^{3)}$ 。

主合金元素をアルミニウムとする AZ系のマグネシウム合 金は，Al-Mg 合金と溶媒元素・溶質元素が入れ替わった関係
にあり，同様の集合組織の変形条件依存性が存在する可能性 があるが，系統的な研究は見あたらない。Al-Mg合金にお ける研究では，溶質濃度が高くなるほど，集合組織形成の特 徵が明瞭となった ${ }^{4)}$ 。そこで，溶質 $\mathrm{Al}$ 濃度が高いAZ80 合金 を対象として，初期集合組織を大きく変えた試料を作製して 高温加工により形成される集合組織形成の特徵を平面ひずみ 圧縮変形により調べたので報告する。

\section{2. 実験方法}

供試材は市販のAZ80 合金押出材である。平面ひずみ圧縮 変形による集合組織形成の特徵が明瞭になるよう, 押出材の もつ先鋭な集合組織を利用して, $\phi 15 \mathrm{~mm}$ の母材から集合組 織の異なる試料を 3 種類作製した。Fig. 1 は試料母材の AZ80 合金押出材の集合組織を示す $\{10 \overline{1} 0\}$ 極点図である。押出方 向を法線とする面を投影面とし，平均極密度を 1 とした等高 線で極密度分布が示されている。極点図の中心部に極密度の 高い集積があり，押出材について報告されている $\{10 \overline{1} 0\}$ 繊 維集合組織が存在していることが確認できる5)。

この押出丸棒から, 優先方位の異なる 3 種類の試験片を機 械加工によって作製した。試験片寸法は $10 \times 10 \times 6.7 \mathrm{~mm}$ であ る。Fig. 2 は試料の幾何学的特徵を示したものである。図中 のRDが平面ひずみ圧縮変形の際の伸長方向である。圧縮面 が斜線面で示されている。試料Aでは圧縮方向 (ND), 試料 Bでは変形が拘束される方向 (TD), そして試料 Cでは伸長

*横浜国立大学大学院生（干 240-8501 神奈川県横浜市保土ヶ谷区常盤台79-5)。Graduate Student, Department of Solid State Materials and Engineering, Graduate School of Yokohama National University (79-5 Tokiwadai, Hodogaya-ku, Yokohama-shi, Kanagawa 240-8501).

**横浜国立大学大学院工学研究院機能の創生部門（横浜市）。Department of Materials Engineering, Faculty of Engineering, Yokohama National University (Yokohama-shi, Kanagawa). 
方向（RD）がそれぞれ〈1010〉が頻度高く配向した集合組 織となる。いずれの試料も $723 \mathrm{~K} て ゙ 1 \mathrm{~h}$ の焼なましを施した後 に試験に供した。焼なまし後の結晶粒径は幾何学補正を加え て $60 \mu \mathrm{m}$ であった。試料 $\mathrm{A}, \mathrm{B}$ および $\mathrm{C} の$ 変形前の結晶方位 分布をEBSD測定の結果をもとに圧縮面を投影面とし

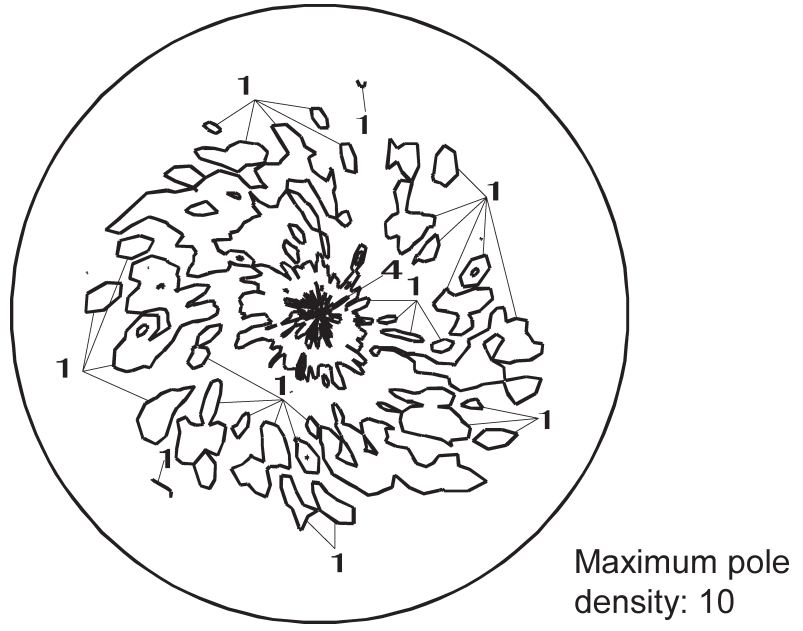

Fig. $1\{10 \overline{1} 0\}$ pole figure of the AZ80 extruded bar. Pole densities are projected onto the plane normal to the extrusion direction. Mean pole density is used as a unit.

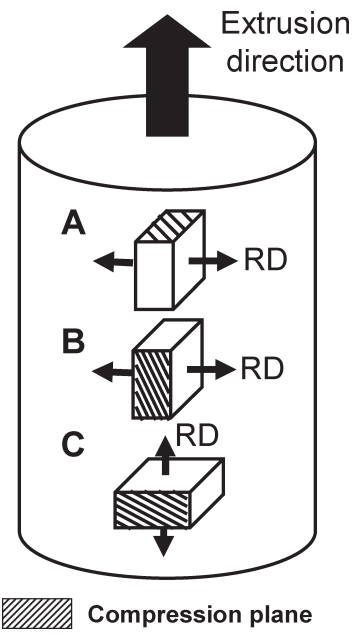

Fig. 2 Geometry of the specimens for plane strain compression.
た（0001）極点図で示したのがFig. 3である。同一押出材か ら作製しているので，最大極密度はAでは7.9，Bでは8.1， Cでは 7.8 とほぼ同一である。最大極密度の位置はAでは外 周部， Bでは $\mathrm{TD}$ から $90^{\circ}$ 離れた大円上，Cでは RDから $90^{\circ}$ 離 れた大円上に存在していた。

平面ひずみ圧縮試験は温度 $723 \mathrm{~K}$, ひずみ速度を $5.0 \times$ $10^{-2} \mathrm{~s}^{-1}$ として真ひずみ-0.4〜 - 1.0 の範囲で行った。所定の ひずみまで変形した後, クロスヘッドを停止するとともに直 ちに加熱炉を開放して試料を取出し, 油冷して組織凍結を 図った。試料の板厚中心部を機械加工等により切出し, 機械 研磨を施した後，Schulzの反射法による集合組織測定に供し た。EBSD（Electron Back-Scattered Diffraction）法による結晶 方位測定は測定面に対してさらに電解研磨を施してから行っ た。

集合組織測定には銅の $\mathrm{K}_{\alpha}$ 線を用いた。 $\{0001\} ，\{10 \overline{1} 0\}$ ， $\{10 \overline{1} 1\} ，\{10 \overline{1} 2\}$ および $\{11 \overline{2} 0\}$ 正極点図，ならびにこれら の正極点図をもとにDahms-Bunge法 ${ }^{6}$ ) で結晶方位分布関 数（ODF）を計算して逆極点図を作成して集合組織を評価 した。

EBSD 法による組織評価では日本電子製走査型電子顕微鏡 JSM-5600とTSL社製OIMシステムを組合せた装置を用い た。隣接する測定点間の最小回転角を計算し， $15^{\circ}$ 以上の場 合に大角粒界 (HAGB) が存在すると判定して結晶粒組織図

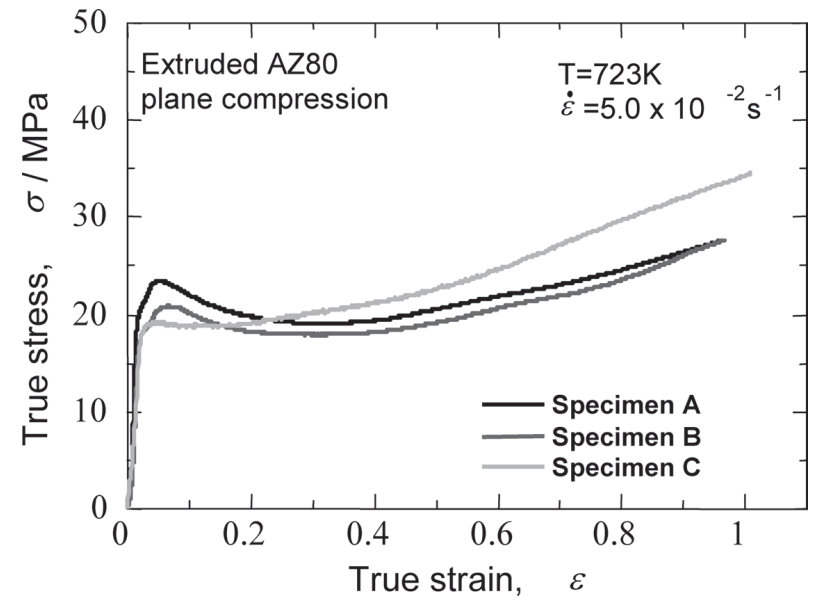

Fig. 4 True stress-true strain curves for the specimens A, B and $\mathrm{C}$.

Levels: 1, 2, 4, 8

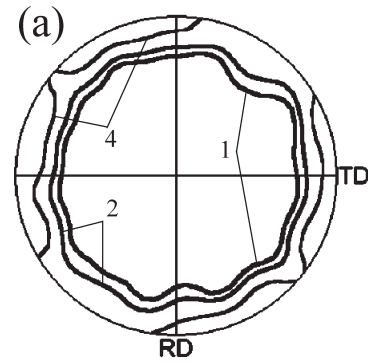

Specimen A

Maximum pole density: $\mathbf{7 . 9}$

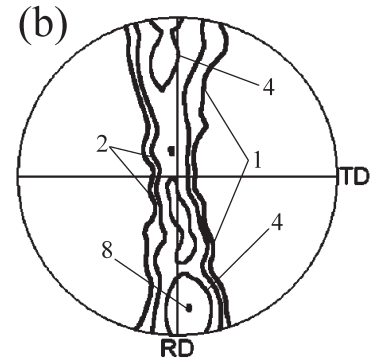

Specimen B

Maximum pole density: $\mathbf{8 . 1}$

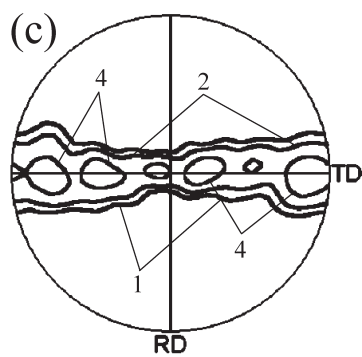

Specimen C

Maximum pold density: 7.8

Fig. 3 (0001) pole figures showing the crystallographic characteristics of the specimens. (a), (b) and (c) show the specimens of A, B and C, respectively. Pole densities are projected onto the compression plane. Mean pole density is used as a unit. 
(a)

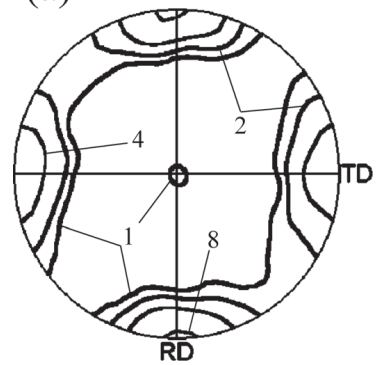

Maximum pole density: 8.7 (b)

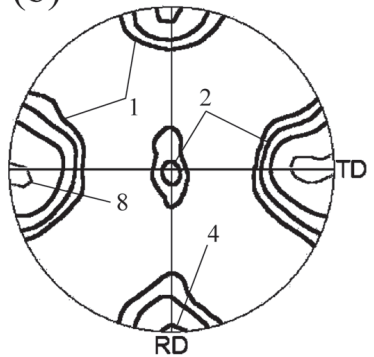

Maximum pole density: 8.8 (c) Levels:1, 2, 4, 8

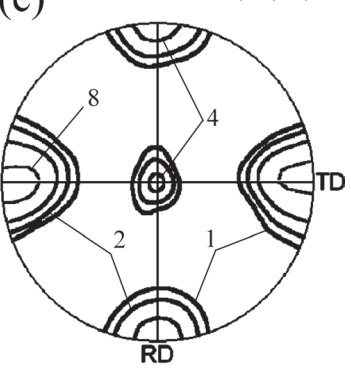

Maximum pole density: 9.7

Fig. 5 (0001) pole figures showing the effect of strain on the texture development of the specimen A. True strains of (a), (b) and $(\mathrm{C})$ are $-0.4,-0.7$ and -1.0 , respectively.

中に実線で表現した。測定は $1.8 \mathrm{~mm} \times 5.4 \mathrm{~mm}$ の領域につい て, $6 \mu \mathrm{m}$ 間隔で行った。

\section{3. 実 験 結 果}

\section{1 真応力-真ひずみ曲線}

Fig. 4 は 3 種類の試料について定めた真応力-真ひずみ曲 線である。ひずみは真ひずみの絶対值で示されている。試料 によって大きさは異なるが，いずれの試料においても， $\mathrm{Al}$ $\mathrm{Mg}$ 固溶体合金 ${ }^{7)}$ や AZ31マグネシウム合金 ${ }^{8)}$ の高温変形と 同様に変形の初期に応力の極大值を示古加工軟化現象が認め られる。〈1010〉が頻度高く配向した方向から圧縮変形して いる試料 $\mathrm{A} の$ 変形応力の極大值が最も高くなっていることが わかる。

\section{2 集合組織}

3.2.1 試料Aにおける集合組織の形成過程

Fig. 5 は試料Aをひずみ (a) $-0.4, \quad$ (b) -0.7 そて (c) -1.0 まで変形した場合の集合組織を示す（0001）極点図で, EBSD測定により描いたものである。いずれの場合も圧縮面 を投影面として描かれている。Fig. 3(a) に示されているよ うに，（0001）極密度は変形前には極点図の外周部に $360^{\circ}$ ほ ぼ均一に分布していたが，ひずみ -0.4 までの変形で極点図 中心部と上下左右の端部の 5 か所にのみ集積が見られる分布 に変化している。上端と下端，左端と右端の極密度の集積を 区別しなければ，極密度の集積位置は3か所である。また， 変形前には認められなかった極点図中心部への極密度の集積 が認められる。この特徵は真ひずみがー 0.7 そして -1.0 へと 増大するにつれてさらに明瞭となっている。

EBSD測定では測定領域中の結晶粒の数が必ずしも十分と は言えないので，X線による集合組織測定を，ひずみ-0.4ま で変形した試料について行った。Fig. 6(a) は（0001）極点 図, Fig. 6(b) は圧縮軸の密度分布を示す逆極点図である。 Fig. 6(a) はFig. 5(a) と類似の極密度分布となっている。ま た，Fig. 6(b) では〈0001〉と〈1010〉の2か所に軸密度が集 積している。

\subsection{2 試料Bにおける集合組織の形成過程}

Fig. 7 は試料Bをひずみ $-0.4,-0.7$ そして -1.0 まで変形し た場合の集合組織を示す（0001）極点図である。Fig. 3(b)

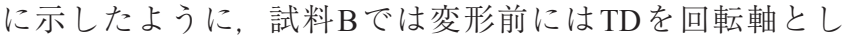
て（0001）が分布している。試料 A と異なって真ひずみ-0.4 ではTD付近には極密度の集積は認められない。しかし，真 (a)

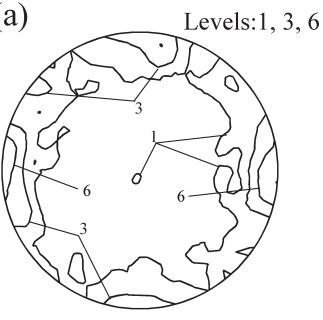

(b)

Maximum pole density: 9.1

Fig. 6 (0001) pole figure for specimen deformed at $723 \mathrm{~K}$, strain rate $5.0 \times 10^{-2} \mathrm{~s}^{-1}$ and strain $-0.4 ;$ (b) inverse pole figure for the same specimen as (a).

ひずみがー1.0になると TD付近にも集積が認められるように なり，試料 $\mathrm{A} の$ 結果と類似した極点図となる。このときの中 心位置への極密度の集積は試料Aでは平均極密度の 10 倍程 度であったのに対し，試料Bでは 22 倍を超える高いものと なった。

\subsection{3 試料Cにおける集合組織変化}

Fig. 8 は試料Cをひずみ $-0.4,-0.7$ そして -1.0 まで変形し た場合の集合組織を示す（0001）極点図である。試料 C は試 料Bを圧縮軸周りに $90^{\circ}$ 回転した幾何学的関係にある。

Fig. 3 (c) と比較すると, 変形前にはRD軸を回転軸として 平均極密度の 2 倍以上の值で連続的に分布していた極密度 が, 真ひずみ-0.4の段階で TD と中心部の中間領域で低くな る傾向が認められる。この傾向は真ひずみ-0.7でさらに顕 著となり, 真ひずみ-1.0では中心部と左右の 3 か所に極密度 の集積が認められる結果となっている。極点図の左端と右端 の集積を同一とみなすと, 極密度の集積位置は2か所であ る。中心部での極密度は, 平均極密度の 26 倍を超えた高い 值となった。さらに, 試料 $\mathrm{A}$ および $\mathrm{B}$ とは異なって, 上下方 向，すなわち，RD方向には極密度の集積は認められない。

\section{3 変形組織}

Fig. 9 は試料Aをひずみ量 -0.4 ならびに一 1.0 まで変形した 後に，圧縮面の組織をEBSDで調べた結果で，圧縮面 が（0001）から 15以内の方位にある結晶粒を塗りつぶして ある。（a）と（b）の観察倍率は同一である。変形前にはほ とんど存在していなかった（0001）が，ひずみ-0.4の段階で 現れ, ひずみ-1.0の段階では, 視野のかなりの部分を占め るようになっている。また，圧縮面での観察であるにもかか 




Maximum pole density: 16 (b)

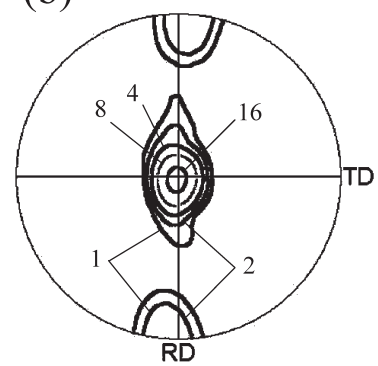

Maximum pole density: 20 (c) Levels:1, 2, 4, 8,16

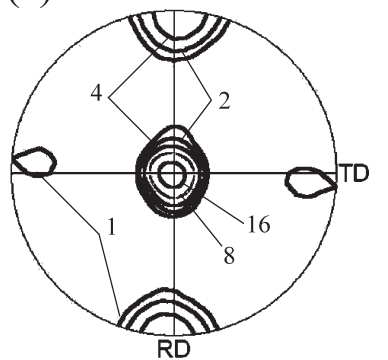

Maximum pole density: 22

Fig. 7 (0001) pole figures showing the effect of strain on the texture development of the specimen B. True strains of (a), (b) and (c) are $-0.4,-0.7$ and -1.0 , respectively.

(a)

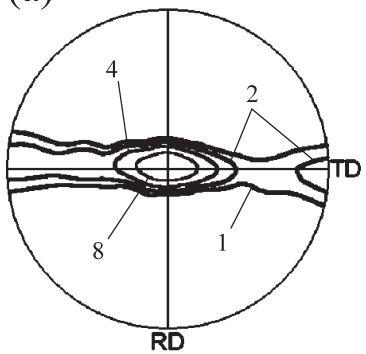

Maximum pole density: 15 (b)

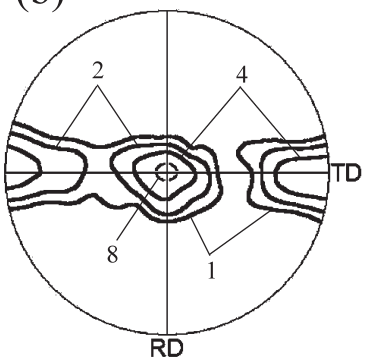

Maximum pole density: 9.3 (c) Levels:1, 2, 4, 8, 16, 24

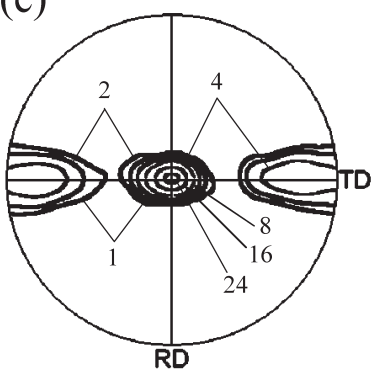

Maximum pole
density: 26

Fig. 8 (0001) pole figures showing the effect of strain on the texture development of the specimen C. True strains of (a), (b) and (c) are $-0.4,-0.7$ and -1.0 , respectively.

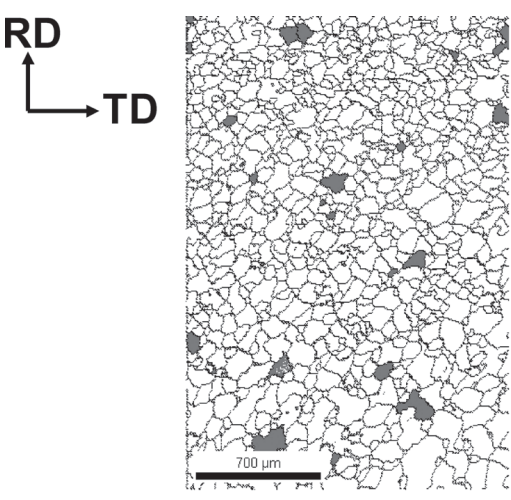

(a)
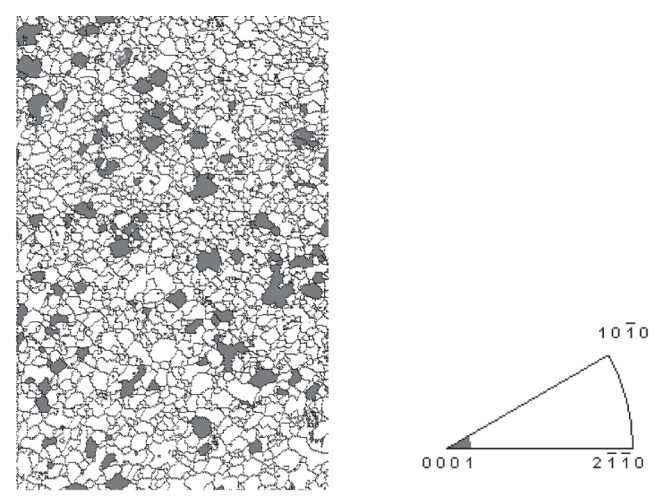

(b)

Fig. 9 Microstructure of specimen A observed by EBSD measurements after deformation up to strains of (a) -0.4 and (b) -1.0 .

わらず結晶粒は伸張方向に伸びていない。さらに，ひずみ -0.4 と-1.0で，結晶粒径に大きな違いはない。むしろひず み量の大きい-1.0の場合の結晶粒径が小さくなっている。

これらの特徵は, 変形中に新粒の生成と粒界移動, すなわ ち動的再結晶が生じていることを示している。このような組 織の特徵は，試料BおよびCにおいても観察された。

\section{4. 考 察}

\section{1 集合組織の成分}

マグネシウム合金を圧延すると，（0001）〈112̄0〉を主成分 とする集合組織が形成されるとの報告がある ${ }^{9)}$ 。Gottstein ら
は温度を変えて平面ひずみ圧縮変形を行いAZ31マグネシウ ム合金の変形集合組織を調べた ${ }^{10)}$ 。そして，473Kならびに $573 \mathrm{~K}$ の変形で $(0001)\langle 11 \overline{2} 0\rangle$ と $(0001)\langle 10 \overline{1} 0\rangle$ が集合組織 の主成分となること, 変形により形成されるのは主とし て $(0001)\langle 10 \overline{1} 0\rangle$ であると報告した。このように，平面ひず み条件での変形集合組織については， $(0001)\langle 11 \overline{2} 0\rangle$ と (0001) $\langle 10 \overline{1} 0\rangle$ とが報告されている。Fig. 5, Fig. 7およびFig. 8 に示した 3 種類の試料の（0001）極点図では, いずれの場 合にも中心部に極密度の高い集積が認められる。このことは AZ80においても類似の集合組織が形成されていることを示 唆している。実際，後に示すように，（0001）〈1120〉ならび 




(a)

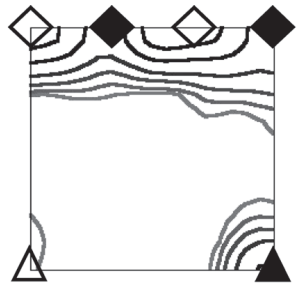

$\left(\varphi_{2}=\mathbf{3 0}{ }^{\circ}\right)$

$\diamond\{0001\}<11 \overline{2} 0>\quad \square\{10 \overline{1} 0\}<11 \overline{2} 0>$

$\Delta\{11 \overline{2} 0\}<10 \overline{1} 0>\quad \Delta\{11 \overline{2} 0\}<0001>$

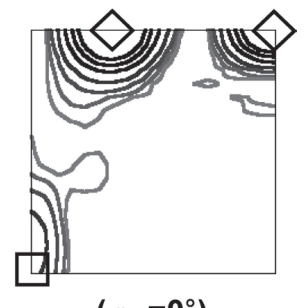

$\left(\varphi_{2}=0^{\circ}\right)$

(b)

(c)

Fig. $10 \varphi_{2}$ sections for specimens $(\mathrm{a}) \mathrm{A}\left(\varphi_{2}=0^{\circ}\right.$ section $),(\mathrm{b}) \mathrm{B}\left(\varphi_{2}=30^{\circ}\right.$ section $)$ and $(\mathrm{c}) \mathrm{C}\left(\varphi_{2}=0^{\circ}\right.$ section $)$, after the deformation up to a true strain of -1.0 .

に $(0001)\langle 10 \overline{1} 0\rangle$ の存在が確認された。また，真ひずみ-1.0 まで変形した後の（0001）極点図における中心位置での極密 度の集積度は, 変形前には集積がなかった試料 Aでは平均極 密度の10倍程度の集積にとどまるのに対し，変形前に集積 のあった試料 $\mathrm{B} て ゙ は 22$ 倍, 試料 Cでは26倍に達していた。 このことは，（0001）（圧縮面）が変形に対して安定で，かつ 動的再結晶中に消滅しない方位であることを意味している。

さらに, Fig. 5, Fig. 7およびFig. 8の極点図では中心部以 外にも極密度の集積がある。このことは従来報告された優先 方位以外の結晶方位が優先方位として本合金の高温加工で存 在していることを意味している。そこで，EBSDによる測定 結果を元にODFを定めて優先方位を調べた。

Fig. 10 はひずみー1.0まで変形した 3 種類の試料について定 めた $\varphi_{2}=0^{\circ}$ るいは $\varphi_{2}=30^{\circ}$ 断面である。方位密度の高い位置 の指数が図の外側に示されている。なお, ここでは $\left(\varphi_{1}, \Phi, \varphi_{2}\right)$ が $(0,0,0)$ の場合に $(0001)\langle 11 \overline{2} 0\rangle$ となる座標系を用いてい る。ここに示した $\varphi_{2}$ 断面および他の $\varphi_{2}$ 断面から, 真ひずみ -1.0 までの変形により，3種類の試料に共通して（0001） $\langle 10 \overline{1} 0\rangle$ および $\{11 \overline{2} 0\}\langle 10 \overline{1} 0\rangle$ が見出された。また，変形前 に存在する $(0001)\langle 11 \overline{2} 0\rangle$ (Fig. 10(b)) ならびに $\{10 \overline{1} 0\}$ 〈0001〉（Fig. 10(a)）はひずみー1.0まで変形しても残存する ことが確認された。3.2.2で示した，試料 Bを真ひずみ -1.0 まで圧縮変形した場合に TDに現れる集合組織成分も $\{11 \overline{2} 0\}$ $\langle 10 \overline{1} 0\rangle$ であった。

$(0001)\langle 10 \overline{1} 0\rangle$ は変形前の A 試料にはほとんど存在してお らず，Fig. 9 に見られる動的再結晶によってこの方位が生成 された可能性が高いと考えられる。JinらはAZ31合金の熱間 圧延材に現れる底面集合組織は，変形初期の双晶により形成 された（0001）方位粒の成長によると報告した ${ }^{11 ） 。 F i g . ~} 9$ に 示した試料AのEBSD測定では双晶は観察されないが，この 試料で $\{10 \overline{1} 2\}$ 双晶が活動すると，〈112̄0〉まわり $86^{\circ}$ 回転に よって, 変形前には（0001）極点図の外周部に頻度高く存在 していた（0001）がこの極点図の中心部に移動することにな る。したがってこの方位の領域が動的再結晶によって成長す れば（0001）（圧延面）を成分とする集合組織が形成される ことになる。しかし，これにより $(0001)\langle 10 \overline{1} 0\rangle$ が発達する かについては今後さらに詳細な検討が必要である。

\section{2 優先方位と平面ひずみ圧縮変形}

転位の溶質原子䨌囲気引きずり運動が変形を支配する場合 に $\mathrm{Al}-\mathrm{Mg}$ 固溶体合金に粒界移動によって形成される集合組

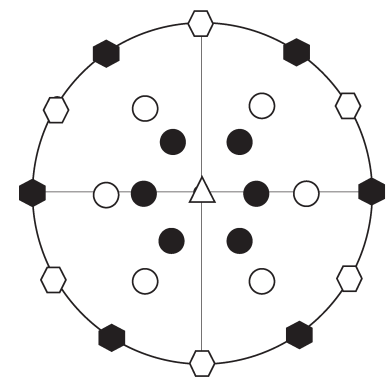

(a)

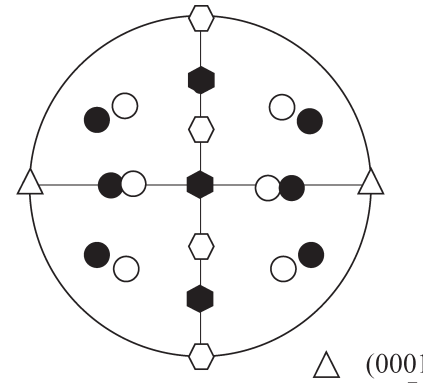

(b) $\triangle \quad(0001)$

$\bigcirc\{11 \overline{2} 2\}$

$<11 \overline{2} 0>$
Fig. 11 Standard stereographic projection showing (0001), $\{10 \overline{1} 0\}$ and $\{11 \overline{2} 2\}$ planes and $\langle 11 \overline{2} 0\rangle$ and $\langle 11 \overline{2} 3\rangle$ directions; (a) $(0001)\langle 10 \overline{1} 0\rangle$ and (b) $\{11 \overline{2} 0\}\langle 10 \overline{1} 0\rangle$.

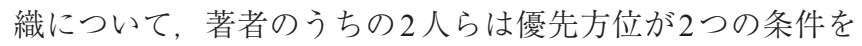
満足していることを見出した。第 1 は Taylor 因子との対応で ある。 $\mathrm{Al}-\mathrm{Mg}$ 合金に現れた優先方位はTaylor因子が小さく， それゆえ他結晶粒を消費して成長できる方位と考えられる。 そして，第2は変形に対して安定な方位であることである。 $\mathrm{A} 1-\mathrm{Mg}$ 合金の高温変形では, いわゆる変形の安定方位とは異 なる集合組織が粒界移動によって形成されるが, 第 1 の条件 と第2の条件を同時に満足する結晶方位として理解された。

Fig. 4 に観察される本合金における加工軟化型の応力ーひ ずみ曲線は, 本実験の変形条件でも $\mathrm{Al}-\mathrm{Mg}$ 固溶体合金の場 合と同様に転位の溶質原子雾囲気引きずり運動が变形を支配 していることを意味している。それゆえ, 集合組織の特徵も 上記の2点の特徵を満足している可能性がある。 HCPの Taylor 因子として定まったものはないので，上述の第2の点 から，すべての試料で出現した結晶方位について検討した。

Fig. 11 は活動すべり系と平面ひずみ圧縮変形の関係を示す 標準ステレオ投影図で (a)が $(0001)\langle 10 \overline{1} 0\rangle$, (b) が $\{11 \overline{2} 0\}\langle 10 \overline{1} 0\rangle$ に対応している。マグネシウムおけるすべり系は, 常温付近 では底面すべり系 $(0001)\langle 11 \overline{2} 0\rangle$ であるが，高温になると， 柱面すべり系 $\{10 \overline{1} 0\}\langle 11 \overline{2} 0\rangle$, ならびにc軸方向への変形に 寄与できる錐面すべり系 $\{11 \overline{2} 2\}\langle\overline{1} 123\rangle$ の活動も可能になる ことが古くから知られている ${ }^{12), 13)}$ 。Fig. 4 に見られるよう に, 底面すべり系の活動が最も困難であると考えられる試料 の $\mathrm{A}$ の変形応力が 3 種類の試料のうちで最も高い事実は, こ の温度でも底面すべり系の活動が最も容易であることを示唆 
している。

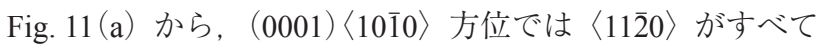
圧縮面に平行なために圧縮変形に寄与できないことがわか る。すなわち，底面すべり系も柱面すべり系も活動が期待で きない。一方この方位においては，錐面すべり系 $\{11 \overline{2} 2\}\langle\overline{1} \overline{1}$ 23〉がND-RD面を対称中心として鏡像の関係にある形で 4 種存在している。これらが等価に活動すると，平面ひずみ条 件を満足し，かつ結晶回転も生じない変形が可能である。す なわち，(0001）〈10 10$\rangle$ はすべり変形に対して安定な結晶方 位であると考えられる。一方（b）に示す $\{11 \overline{2} 0\}\langle 10 \overline{1} 0\rangle$ 方 位では，柱面すべり系が上下に対称に存在し，〈1120〉方向 のうちの2つが側面方向への成分をもたない。すなわち平面 ひずみ条件を満足し，結晶回転を生じない変形が柱面すべり 系の活動によって可能である。ここでは詳細に記さないが, 変形後も残存していた, $(0001)\langle 11 \overline{2} 0\rangle$ ならびに $\{10 \overline{1} 0\}$ 〈0001〉についても同様の考察から, 変形に対して安定であ ることがわかった。前記の 2 方位と異なってこれらの方位が 優先方位として発達しないのは，粒界移動に対する優先性の 差異に起因すると推測されるが, この点については今後さら に検討したい。

\section{5. 結言}

AZ80実用マグネシウム合金を対象に，マグネシウム固溶 体合金の高温加工による集合組織形成の特徵を明らかにする ために，特徵的な集合組織を有する 3 種類の試料を用意して 平面ひずみ圧縮変形を実施し，集合組織の形成過程を実験的 に調べた。その結果，以下の結論を得た。

(1) 高温平面ひずみ圧縮加工によって, 動的再結晶が生じ るとともに集合組織が形成される。

(2) 真ひずみ-1.0までの変形によって形成される集合組
織は, $(0001)\langle 10 \overline{1} 0\rangle, \quad\{11 \overline{2} 0\}\langle 10 \overline{1} 0\rangle, \quad(0001)\langle 11 \overline{2} 0\rangle$ ならび に $\{10 \overline{1} 0\}\langle 0001\rangle$ などの成分から構成される。

（3）見出された集合組織の成分は，変形前にはほとんど存 在していなかったものと, 変形前に存在していたものの2種 類があるが，いずれの成分も結晶すべり変形による平面ひず み圧縮変形に対して安定な方位である。

（4）（0001）(圧縮面）集合組織は，この方位が変形前に存 在している場合に極めて先鋭になる。このことは，この方位 が変形に対して安定で，かつ動的再結晶中に他の結晶粒に消 費されにくい結晶方位であることを意味している。

\section{謝 辞}

本研究費の一部は，軽金属奨学会の支援による。ここに記 して感謝する。

\section{参 考 文 献}

1）金子純一，菅又 信：軽金属，54 (2004)，484-492。

2）戸澤康壽：軽金属, 51 (2001), 492-497.

3) K. Okayasu, H. Takekoshi and H. Fukutomi: Mater. Trans., 48 (2007), 2002-2007.

4）岡安和人, 竹腰弘毅, 榊原将之, 福富洋志：日本金属学会誌, 73 (2009), 58-63.

5) T. Al-Samman: Acta Mater., 57 (2009), 2229-2242

6) M. Dahms and H. J. Bunge: J. Appl. Crystallogr., 22 (1989), 439-447.

7) K. Okayasu and H. Fukutomi: Mater. Sci. Forum, 495-497 (2005), 579-584.

8) L. Helis, K. Okayasu and H. Fukutomi: Mater. Sci. Eng. A, 430 (2006), 98-103.

9）大年和徳，勝田基嗣：軽金属，51 (2001)， 534-538.

10) G. Gottstein and T. Al-Samman: Mater. Sci. Forum, 495-497 (2005), 623-632.

11) Q. Jin, S.-Y. Shin and S.-G. Lim: Scr. Mater., 55 (2006), 843-846.

12) H. Yoshinaga and R. Horiuchi: Trans. JIM, 4 (1963), 1-8.

13）安藤新二, 中村寛治, 高島和希, 頓田英機：軽金属，42（1992）, $765-771$. 